\title{
Firm Credit Rating as a Measure of Organizational and Financial Performance
}

Manisha Singal*

Strategy in Hospitality Management, Pamplin College of Business, Virginia Tech, Blacksburg, VA, USA

\section{Introduction}

When conducting research in corporate strategy, scholars are interested in understanding the effect of strategic actions on organizational performance, and oftentimes the firm's financial performance becomes the ultimate dependent variable of interest. Although recent research has moved to using a holistic approach in examining the triple bottom-line effect, or a balanced score-card approach when evaluating a firm's performance in relation to several stakeholders, considering the salience of investors as stakeholders and suppliers of capital, the predominant interest still seems to lie in financial performance. Despite this interest, scholars have not agreed upon a measure or even a set of measures that are universally accepted. If there are instantaneous or quick changes that affect a firm, it is reasonable to evaluate the anticipated effect of the change (merger, CEO turnover, or earnings) on firm value by measuring stock returns around the announcement of such a change. For example, if the acquirer's stock price falls immediately after the merger announcement, the stock market's reaction implies that the acquisition will hurt the bidder firm's future financial performance. However stock returns, and stock price changes are often considered "fleeting" measures of firm performance. Similarly other measures like accounting measures have also come in for criticism as "backward looking".

While reviewing the construct of organizational performance in strategy research, Combs et al. [1], identified three dimensions of organizational performance; accounting returns, stock market returns, and growth prospects. They urge scholars to use variables that capture the multidimensionality of the organizational performance construct, while distinguishing it from the operational performance construct like marketing and sales outcomes or human resource outcomes that serve as antecedents to the overall organizational performance measure.

My purpose in this note is to suggest an additional measure of organizational performance, i.e. a firm's credit rating that may at least partially capture the different dimensions of the performance construct.

\section{Firm Credit Rating: Another Performance Measure}

There is considerable support for use of credit rating as a tool for assessing financial performance. Standard and Poor's explains that "while a key component of credit rating analysis is the evaluation of historical data, ratings opinions are designed to be forward looking. For example, in assigning its ratings, Standard \& Poor's factors in anticipated ups and downs of business cycles in specific industries as well as trends and events that can be reasonably anticipated." Moody's rating agency writes that ratings "are certainly based on the current financial strength of the issuer, they incorporate expectations of future performance as well - not just issuer performance, but the industry and overall economy." According to Kisgen [2], "Credit ratings may provide information on the quality of a firm beyond other publicly available information. Rating agencies may receive significant company information that is not public. Credit agencies might also specialize in the information gathering and evaluation process and thereby provide more reliable measures of a firm's creditworthiness." Boot et al. [3] argues that "rating agencies could be seen as information-processing agencies that may speed up the dissemination of information to financial markets."

While credit rating is designed to measure a firm's solvency, it depends heavily upon a firm's past and current performance, as well as expected future performance. To consider it as an appropriate gauge for performance evaluation, there should be a direct relationship between the credit rating measure and other measures of expected firm performance. Indeed, research has shown that changes in credit ratings immediately affect stock prices and bond prices in the expected direction [4-7]. Thus, the credit rating of the firm can be considered a reasonable measure of organizational performance.

\section{Firm Credit Rating: Applications}

My focus here is not on a particular event but on a cross-sectional evaluation of firms with different strategies or on a time-series where corporate strategies of firms evolve or change over a period of time instead of at a point in time. Examples include a cross-sectional comparison of firms with an active franchising policy (Dunkin Donuts) and firms where the properties are primarily company-owned and operated (Starbucks); a comparison between casino hotel firms and non-casino hotel firms; low leverage firms and high leverage firms; family-controlled firms and non-family firms; or firms with strong corporate social responsibility (CSR) policies and firms with weak CSR policies. Similarly, time-series analysis may be necessary to evaluate the performance of firms following involuntary CEO turnover; expansion into international markets; introduction of calorie and nutritional information; and changes in the business cycle.

For such cross-sectional and time-series evaluations, Tobin's Q is the preferred measure of financial performance. However, instead of relying on one measure of financial performance, researchers also report results with other measures such as return on assets and stock returns. It is not clear that the flow variables (return on assets and stock returns) are appropriate for measuring changes in financial performance especially in a time-series analysis. As noted by Gregory and Whittaker [4] and based on theoretical arguments and numerical examples, stock returns are weak measures of the efficacy of corporate strategy (such as CSR) if markets are efficient because stock returns are

*Corresponding author: Manisha Singal, Strategy in Hospitality Management, Pamplin College of Business, Virginia Tech, Blacksburg, VA, USA, Tel: (540) 231-4569 Fax: (540) 231-8313; E-mail: msingal@vt.edu

Received June 25, 2013; Accepted June 28, 2013; Published July 01, 2013

Citation: Singal M (2013) Firm Credit Rating as a Measure of Organizational and Financial Performance. J Bus \& Fin Aff 2: e135. doi:10.4172/2167-0234.1000e135

Copyright: ( 2013 Singal M, et al. This is an open-access article distributed unde the terms of the Creative Commons Attribution License, which permits unrestricted use, distribution, and reproduction in any medium, provided the original author and source are credited. 
realized immediately upon the release of new information regarding that strategic initiative. In general, flow variables suffer from their transitory nature in measuring the impact of corporate strategy on financial performance unless there is a significant change in that strategy during the period under observation.

A firm's credit rating is another stock variable (as opposed to flow variables), for measuring performance, which may have advantages over Tobin's Q, the most commonly employed measure. Tobin's Q depends greatly on accounting numbers (book values) that are based on accounting policy choice and contain limited information about current and future firm performance.

\section{Relative Biases in Firm Credit Rating and Tobin's Q}

Since credit rating and Tobin's Q are constructed differently, they measure financial performance in different ways. Tobin's $Q$ is intended to measure the value of future growth opportunities based on the difference between market and replacement values of a firm whereas firm credit rating is a measure of the stability of a firm's financial condition. Since Tobin's Q depends on growth opportunities, it is usually lower for old firms, for firms in mature or declining industries, and for firms that are large in size. On the other hand, firm credit rating is usually higher for old firms, for firms in mature industries, and for firms that are large in size. The differences in their assessment of financial performance are also reflected in the low correlation between the two measures: For a sample of firms that were in the S\&P 500 at any time between 1991 and 2011, the correlation between the two measures was 0.29 , and statistically significant (author's calculations).

\section{Firm Credit Rating: Implementation and Limitations}

Monthly historical firm credit ratings can be obtained from Standard and Poor's Compustat database. Ratings are assigned as letter grades going from a top rating of AAA down to a $D$ when a firm defaults. The ratings are easier to handle if they are coded into numerical scores where AAA takes the value of 26 and D has a value of 1 . They can also be partitioned into investment grade (rating of 16 or higher) and below investment grade (junk rating).

Though firm credit rating is an overall measure of financial performance because it accounts for anticipated changes in the economic or industrial environment and relies on substantial private information available to the rating agencies, it has at least two important limitations. First, credit ratings are available mostly for large firms.
However, those ratings include more than $75 \%$ of publicly-traded firms with a market capitalization of more than $\$ 200$ million. In addition, it is not necessary that a firm carry debt for it to be rated (for example, see Apple Inc.). Ratings are also available for large private firms where corporate financial information may not be publicly available. Second, changes to a firm's credit rating are infrequent and ratings may not change for several months or even a few years. Infrequent changes reduce variability in ratings that may negatively impact the power of empirical tests. On the other hand, absence of superfluous changes may reduce noise in those tests.

\section{Conclusion}

In this note, I have suggested an alternative measure of financial performance - firm credit rating - a measure that has been used for decades in evaluating a firm's financial condition and in the pricing of its debt. Changes in a firm's credit rating also affect stock prices implying that it is captures the dimension of performance. In addition, since Tobin's Q, and credit rating, assesses different aspects of financial performance, we can consider using firm credit rating as an additional or alternative measure of financial performance. While the credit rating of a firm is a useful measure for evaluation of organization performance in all industries, it may be particularly useful for industries that are highly capital-intensive or leveraged like those in real estate or the hotel sector. Future empirical work will eventually determine the utility and effectiveness of firm credit ratings relative to Tobin's $Q$.

\section{References}

1. Combs JG, Crook TR, Shook CL (2005) The dimensionality of organizational performance and its implications for strategic management research. Research methodology in strategy and management 2: 259-286.

2. Kisgen DJ (2006) Credit Ratings and Capital Structure. The Journal of Finance 61: 1035-1072.

3. Boot AWA, Milbourn TT, Schmeits A (2006) Credit ratings as coordination mechanisms. Review of Financial Studies 19: 81-118.

4. Gregory A, Whittaker J (2012) Exploring the Valuation of Corporate Social Responsibility-A Comparison of Research Methods. Journal of Business Ethics 1-20.

5. Hand JR, Holthausen RW, Leftwich RW (1992) The effect of bond rating agency announcements on bond and stock prices. Journal of Finance 47: 733-752.

6. Kliger D, Sarig O (2000) The information value of bond ratings. The journal of finance 55: 2879-2902.

7. Holthausen RW, Leftwich RW (1986) The effect of bond rating changes on common stock prices. Journal of Financial Economics 17: 57-89. 